\title{
An Empirical Analysis to the Impact of Tax Incentives on FDI after WTO
}

\section{Jue Yan}

Economics Department, Jinan University, Guangzhou, China

Email: yanjue66@gmail.com

How to cite this paper: Yan, J. (2016) An Empirical Analysis to the Impact of Tax Incentives on FDI after WTO. Modern Economy, 7, 1264-1271.

http://dx.doi.org/10.4236/me.2016.711121

Received: September 9, 2016

Accepted: October 7, 2016

Published: October 10, 2016

Copyright (@) 2016 by author and Scientific Research Publishing Inc. This work is licensed under the Creative Commons Attribution International License (CC BY 4.0).

http://creativecommons.org/licenses/by/4.0/

\begin{abstract}
Based on 36 cities' datum, We build a model to examine whether a series of tax incentives to promote FDI inflows have a significant effect or not after 2001. The results showed that: After WTO, preferential tax policies which were taken to promote FDI inflows and upgrade industrial structure indeed had a certain effect. From subregional perspective, preferential tax policies for central and western regions still attract FDI, while the eastern region is no longer significant.
\end{abstract}

\section{Keywords}

Tax Incentives, FDI

\section{Introduction}

Foreign direct investment (FDI, the following uses FDI) as capital inflows cannot only make up for the insufficiency of investment in the host country. Under the action of demonstration effect and spillover effect, FDI can improve the investment rate of the host country, expand exports, increase capital formation capability, increase fiscal revenue, and promote the benign development of national economy.

Since the reform and opening up, for the reason that domestic capital is insufficient, thus the government has developed a series of policies and measures to encourage foreign investment, and also achieved some success. Especially since China's accession to the World Trade Organization (WTO), the amount of foreign direct investment in China showed a growth spurt, even reached $\$ 100$ billion in 2010. At the meantime, FDI also increased investment in the tertiary industry, such as services, and financial services. In 2014 the proportion of FDI which actually used in real estate was as high as 26.95 percent, ranked second only to the manufacturing sector. The ability to undertake industrial transfer in Central Region has enhanced, and thus some industries have begun 
to move from coastal areas to inland. In order to narrow the differences in regional development, to guide FDI transfer to central and western regions, as early as 1999, the State Administration of Taxation has adopted the relevant provision that the corporate income tax rate of FDI enterprises which set up in the Midwest encouraged by the state reduced to $15 \%$.

In order to balance the income tax burden between foreign companies and domestic enterprise, and improve the competitiveness of domestic manufacturers, China has promulgated the new "Enterprise Income Tax Law" in 2008. This implement has ended the tax preference of FDI as long as 30 years in our country. Whether the impact of a series of tax policy on FDI after China joined in WTO had the effect is one of the main objectives discussed in this paper. Due to the special geographical environment and unbalanced regional development condition, the factors that attract FDI between central and western regions are not the same. This article also discusses which factor in different region is the most important.

\section{Literature Review}

For this topic, our scholars have done some relevant research.

Lei Guangping (2006) put it that the reaction to different types of business tax incentives are not the same, for export-oriented FDI, foreign investors can select multiple countries and regions in the international market as an alternative to commodity production, its response to tax incentives is more sensitive. For inward FDI which major facing domestic market, choose to invest in host country has a better geographical advantages than the production in other countries and regions, in general, their response to the tax incentive is not as sensitive to export-oriented enterprises. Tax incentives can neither make up for the defect in the investment climate in the country, nor produce the desired external effects. However, when other factors (such as infrastructure, transport costs, political and economic stability) is substantially equal to a regional tax it is likely to have a great impact on investor choice. However, this effect is not stereotyped, depending on the tax means he used, multinational characteristics, and the relationship between the national tax system and investment between the receiving countries.

Chen Bing (2007) found that: tax incentives is indeed an important driving force to attract foreign investment. At the same factor level of economic development and infrastructure, also have a significant impact on the inflow of foreign capital.

And some scholars study found tax incentives for FDI is not significant. Zhang Yang, Emily (2006) use cross-sectional data of 2003 the provinces and municipalities, drawn from the analysis, in 2003 China's actual foreign direct investment of 535 billion yuan, accounting for $40.17 \%$ of total Hong Kong, Macao and Taiwan regions mainly smallscale labor intensive enterprises, labor costs only larger sensitivity of the foreign companies are not sensitive to tax changes. United States, China and Japan accounted for $17.29 \%$ of total credit is mainly the home country tax type, as long as China's actual tax rate is not higher than the home country tax rates, our tax rate changes no major impact on business investment. Some of the remaining long-term development is the 
main type, the value of our investment in China's economic growth and future market prospects, and therefore sensitive to relatively small tax. Also a key factor model analysis results obtained impact of foreign direct investment of China's economic development level and the degree of openness, the role of taxation in which FDI is not obvious, the variable is not significant.

Cheng Lanfang, Wang Qiang (2008) of 56 selected cities, 1989-Panel Data of 2004, respectively, from the perspective of the whole period and two phases for quantitative analysis examines the market size, infrastructure, labor costs, labor quality, the level of urbanization and the impact of tax incentives on FDI (in urban units, mainly because of incentives towns targeted release) of. The empirical results show that tax incentives throughout the period 1989-2004 in view of the role is to promote, but phased term 1989-1997 Effect is positive in 1998-2004 but there has been a negative impact. The author believes the main reason, with the continuous deepening of reform and opening up, attractive tax incentives to foreign investors gradually weakened, so that the difficulties encountered when a country wants to again by the introduction of tax incentives to foreign central and western regions lagging behind, the basic policy objectives not achieved, resulting in a negative situation.

\section{The Model}

Since the cities as basic unit in China' Reform and Opening, hence this paper selected the city as a cross-section of the panel data. This paper selected 36 cities as samples for analysis. According to the availability of sample data, this paper selects 36 cities' datum from 2001 to 2014, sample data mainly from the "China City Statistical Yearbook".

\subsection{Selected Variables}

This paper mainly figure out whether tax incentives for FDI have the effect or not, and therefore selected FDI in 36 cities as dependent variable, the unit is billion.

According to Dunning [1], pointed out in "eclectic theory of international production": whether the enterprise invest in other country depends on three factors, namely Enterprise Ownership Advantage, internalization advantages and location advantages of the host country which is the key factors, mainly include the following four categories: 1) Market factors, including market size, market growth, the degree of contact with customers, the existing layout of the market. 2) Barriers to trade, including the extent of trade barriers (tariff high or low), local customer preferences. 3) Cost factors, including labor costs, raw material costs, transportation costs. 4) The investment environment, including policies and regulations and the degree of political stability for foreign investment. Therefore, this paper selected the following indicators as variables of the model.

- The level of economic development (GDP): In order to eliminate the influence of demographic factors, we selects the per capita gross national product (GNP) to measure the level of economic development of the region. Dunning's "Eclectic theory" put forward that the location advantage is the ability to absorb FDI in the 
host country, while the more developed the level of economic development in the region, the higher the service which FDI can get in raw materials, industrial products, in general, the better local economic develops the more perfect local government service levels and the legal environment are. Therefore, it is predicted that the total amount of FDI is proportional to the local GDP.

- Infrastructure (infrast): for enterprises, perfect infrastructure means lower operating costs. While Infrastructure includes many aspects, we selects the per capital area of road pavement to measure the level of infrastructure of a city. The more developed urban transportation is, the more FDI inflows. Therefore, it is predicted that the total amount of FDI is proportional to the local infrast.

- Trade openness (transp): Generally, according to Jiechang Xie [2], the greater the degree of openness is, foreign investment. The higher the degree of freedom in foreign commercial activities are. We selected the import and export volume to measure the trade openness of a region. The greater the degree of openness is, the more the total amount of FDI absorption are. Therefore proportional.

- Labor costs (wage): we selected the average wage to measure the labor costs of a region. Labor costs is an important aspect to a company, if companies obtain lower labor costs to operate, means greater profits. However, due to the low level of wages means Labor quality is not high, it is less attractive for high-tech enterprises, thus it is uncertain how the level of average wage attractive FDI inflows.

- Tax factor (tax): For the reason that the actual tax burden of enterprises are difficult to measure, we take measures which Chen Bin [3] used by tax incentives index to reflect the extent of preferential tax policies in a region, the bigger tax cincentives index is, the greater degree of preferential tax policies which used on FDI are, In general, the greater the degree of tax incentives are, the lower tax burden the companies are, the greater the profit after tax is. Therefore, we can predict the index is proportional to FDI inflows.

China's tax incentive policies are subregional, according to Zhangyang [4], Before 2001, China's tax benefits progressively decreased in accordance with special economic zones-the coastal open cities - the capital city of inland, so in 2001, tax index of SEZ is assigned to number 3 , open coastal city assigned to number 2 , the inland capital city assigned to number 1. IN 2001, the western development strategy has implemented, including Guizhou, Sichuan, Yunnan and other 12 western provinces were given more autonomy in tax incentives, taking the timeliness of the policy in 2002 into consideration, we give the western provincial capital tax incentives index assigned to 2, other areas remain unchanged. The new enterprise income tax law enacted in 2007 provision that from 2008, except for Western regions, Enterprise Income Tax in other parts merger, it canceled the original tax incentives to FDI. Therefore, since 2008, Tax index in special economic zones, coastal open cities and other regions besides western were adjusted to number0, the index of tax incentives in Western Development Region remains unchanged. The impact of different tax incentives on FDI from 2001 to 2014 according to the above analysis is as following Table 1. 
Table 1. Index tax incentives in different cities.

\begin{tabular}{|c|c|c|c|}
\hline Region & 2001 & 2001-2007 & $2008-2014$ \\
\hline SEZ & 3 & 3 & 0 \\
\hline Coastal cities & 2 & 2 & 0 \\
\hline Inland capital cities & 1 & 2 (west), 1 (others) & 2 (west), 0 (others) \\
\hline
\end{tabular}

In this paper, a total of five selected indicators to measure the impact of different factors on FDI inflows, Table 2 shows the sources and the expected results of each variable.

\subsection{The Model Set}

Based on the above variables, we adopted regression model as follows:

$$
\begin{aligned}
\text { LnFDIit } & =\beta_{\mathrm{i}}+\beta_{1} \text { taxit }+\beta_{2} \text { Lngdpit }+\beta_{3} \text { Lntranspit } \\
& +\beta_{4} \text { Lninfrastit }+\beta_{5} \text { Lnwageit }+\varepsilon \text { it }
\end{aligned}
$$

where, $i=1,2,3, \ldots, 44$, representatives of the selected 36 cities, $t=1,2, \ldots, 14$ representatives of different years between 2001-2014, $\beta_{i}$ representatives of the effects does not change with time in different regions, $\beta_{1}, \beta_{2}, \beta_{3}, \beta_{4}, \beta_{5}$ is the regression coefficient for each variable, representing for the impact each factor influenced on FDI, $\varepsilon$ it is a random error term model.

\subsection{An Empirical Analysis}

Due to the length of time is a total of 14 years, the sample size are 36 cities, so this is a short panel model, before panel data regression. We should decide this model is applicable to fixed-effect or random effects. Fixed effects model refers to the slope of the panel data model does not change with cross-sectional and times, intercept only with individual differences in changes and do not change with time. Random effects model was used to measure the differences in each cross-section through the error term. Hausman test results by stata 12 is in the following Table 3.

Where in the test results $\mathrm{H}=14.76, \mathrm{P}>\mathrm{H}=0$, reject the null hypothesis, you should use the fixed effects model.

Before regression analysis, the descriptive statistics to sample data are in the following Table 4.

From Table 4, the panel has a good distribution of data to ensure the suitability of taking the fixed effects model analysis.

Regression analysis used in stata12 of the total sample as follows (Table 5).

From the regression results of the overall sample, the $\mathrm{R} 2$ in model reached $64.66 \%$. It indicates that the model fitting degree is better. Tax incentives are significant for FDI inflows, the coefficient is 0.1190 , namely when tax benefits rose by one unit, FDI will grow 11.9 percent. In the other control variables, the import and export volume is significant to FDI inflows, the coefficient is 0.4367 , namely when imports and exports volume increase $1 \%$, FDI grows up $43.67 \%$. The average wage of workers is also remarkable, 
Table 2. Variables and assumptions indicators of the relationship between FDI.

\begin{tabular}{cccc}
\hline Explanatory variables & Index & Indicator meaning & Expected relationship \\
\hline The level of economic development & Lngdp & The per capita gross national product & Positive correlation \\
Infrastructure & Lninfrast & The per capital area of road pavement & Positive correlation \\
The degree of development of trade & Lntransp & The import and export volume & Positive correlation \\
Labor cost & Lnwage & The average wage & Uncertain \\
Tax factors & tax & Tax incentives index & Positive correlation \\
\hline
\end{tabular}

Table 3. Hausman test results.

\begin{tabular}{ccccc}
\hline & (b) fe & $(\mathrm{B}) \mathrm{re}$ & (b-B) difference & Sqrt(diag(V-b-V-B))S.E \\
\hline Tax & 0.1189944 & 0.0922457 & 0.0267487 & 0.0085597 \\
Lngdp & 0.1048469 & 0.2870212 & -0.1821743 & 0.0921263 \\
Lntransp & 0.4366769 & 0.5556756 & -0.1189987 & 0.0590528 \\
Lninfrast & -0.0691904 & -0.0711894 & 0.001999 & 0.0441239 \\
Lnwage & 0.5952405 & 0.2123589 & 0.3828816 & 0.1252333 \\
cons & -0.5195945 & -0.8673761 & 0.3477816 & 0.1783883 \\
\hline
\end{tabular}

Table 4. Descriptive statistics of variables.

\begin{tabular}{|c|c|c|c|c|c|}
\hline Variable & Obs & Mean & Std. dev & Min & Max \\
\hline FDI & 455 & $203,990.1$ & $27,2640.2$ & 976 & $2,067,229$ \\
\hline TAX & 504 & 1.150794 & 1.009438 & 0 & 3 \\
\hline GDP & 504 & $43,885.74$ & 29056.37 & 5885 & 149,495 \\
\hline TRANSP & 498 & $3,793,101$ & 8324264 & 16.0901 & $5.37 \mathrm{e}+07$ \\
\hline INFRAST & 466 & 11.98464 & 7.427021 & 2.35 & 64 \\
\hline WAGE & 504 & $32,404.25$ & $17,084.79$ & 8982 & $10,7396.8$ \\
\hline
\end{tabular}

Table 5. Overall regression results.

\begin{tabular}{cc}
\hline Cons & $-0.5195945(-1.48)$ \\
Tax & $0.1189944(3.31)^{*}$ \\
Lngdp & $0.1048469(0.48)$ \\
lntransp & $0.4366769(5.11)^{*}$ \\
lninfrast & $-0.0691904(-0.6)$ \\
Lnwage & $0.5195945(2.48)^{*}$ \\
$\mathrm{R}^{2}$ & 0.6466 \\
$\mathrm{~F}$ & 118.92 \\
\hline
\end{tabular}

Note: The $\mathrm{t}^{* * *},{ }^{* *},{ }^{*}$ represent of $10 \%, 5 \%$ and $1 \%$ significance level. 
and is positively correlated with FDI inflows. So it can be seen that FDI prefer to highquality workers areas.

In order to understand more deeply which is the difference between eastern region, western region and central region about attracting FDI from 2001, we established three regression analysis for each region, the results shown in the following Table 6, where the Equation (1) stands for eastern region, Equation (2) stands for the central region, and Equation (3) stands for the western region.

It can be seen that for the eastern region, the per capita gross national product, the average wage and the import and export volume are significant for FDI, the coefficients of which are $1.5654,0.4450,-1.2060$, thus the developed economic environment is the main factor to attract FDI inflows. Again eastern open and free trade environment is more suitable for foreign-funded enterprises, finally, in order to control labor costs, FDI in the eastern region still tend to choose low-wage labor, but this effect is very small. On the contrary, tax incentives is not significant. With respect to the eastern and western regions, the level of economic development of the central region is in the middle position, therefore the per capita gross national product is significant, tax incentives is also significant for FDI, which effectively reduce FDI tax costs and improve operating margins. For the western region, the western development strategy started to give tax incentives to FDI in the western region has played a significant role from 2001, the coefficient is 0.3012 , that is, for the western region, when tax incentives index increased by one unit, it can increase 30.12 percent of FDI inflows.

\section{The Conclusions and Policy Recommendations}

1) A series of tax incentives since the implementation of China's accession to WTO have played an important role in promoting FDI inflows. Taxation is one of the production costs to enterprises. Improving tax incentives will have a certain appeal to foreign-funded enterprises. However, from the regression results in the subregion, FDI in central region is more sensitive to tax incentives; therefore tax incentives should highlight its regulatory role. We should continue to implement preferential tax policies for the western region, which are also applied to the central region at the same time.

Table 6. Regression results for different regions.

\begin{tabular}{cccc}
\hline Variable & Equation $(1)$ & Equation $(2)$ & Equation $(3)$ \\
\hline Tax & $-0.0222879(-0.27)$ & $0.3720648(2.93)^{\star *}$ & $0.3012035(2.45)^{\star *}$ \\
Lngdp & $1.56541(2.29)^{\star *}$ & $1.492713(2.66)^{\star *}$ & $-0.6123902(-0.88)$ \\
Lntransp & $0.4450334(3.46)^{*}$ & $0.27308993(1.24)$ & $1.243981(8.5)^{\star}$ \\
Lninfrast & $-0.2029972(-0.72)$ & $-0.2981579(-1.18)$ & $0.706661(1.52)$ \\
Lnwage & $-1.205989(-2.17)^{* *}$ & $-0.0842086(-0.11)$ & $-0.4356984(-0.58)$ \\
Cons & $-0.0550826(-0.07)$ & $-1.445345(-0.17)$ & $-4.389396(-4.64)^{\star}$ \\
$\mathrm{R}^{2}$ & 0.7529 & 0.6896 & 0.6336 \\
$\mathrm{~F}$ & 35.96 & 49.34 & 34.37 \\
\hline
\end{tabular}


2) High-quality personnel have become popular to FDI, especially in the eastern coastal region of FDI. They need more high-level $\mathrm{R} \& \mathrm{D}$ talents. This is another side to verify that FDI has shifted from the initial labor-intensive enterprises to technologyintensive foreign investment

3) Since China's accession to WTO, in order to optimize the country's domestic economic and trade conditions, the government has made a series of efforts. It can be seen that the attractiveness of open business environment for foreign investment is strong, so the government should continue to strengthen trade partnership cooperation with countries in the world, and sign bilateral or multilateral trade agreements to eliminate trade friction.

4) The potential market size of eastern and central regions is a major factor for FDI. Therefore, eastern and central regions should continue to promote the economic development level and play the advantages of scale and clustering.

\section{References}

[1] Dunning, J.H. (1988) Explaining International Production. Unwin Hyman, Boston.

[2] Xia, J.C. and Li, Z. (2004) Tax Incentives and FDI: Theoretical Analysis and Chinese Inspection Experience. Tax, 9, 50-54.

[3] Chen, B. (2007) Attracting FDI Empirical Analysis of the Effectiveness of Tax Incentives. Reform and Strategy, 1, 72-74.

[4] Zhang, Y. and Liu, H. (2006) Effect of Taxation on Foreign Direct Investment. Tax Research, 4, 38-41.

Submit or recommend next manuscript to SCIRP and we will provide best service for you:

Accepting pre-submission inquiries through Email, Facebook, LinkedIn, Twitter, etc.

A wide selection of journals (inclusive of 9 subjects, more than 200 journals)

Providing 24-hour high-quality service

User-friendly online submission system

Fair and swift peer-review system

Efficient typesetting and proofreading procedure

Display of the result of downloads and visits, as well as the number of cited articles

Maximum dissemination of your research work

Submit your manuscript at: http://papersubmission.scirp.org/

Or contact me@scirp.org 